\title{
Telecollaboration in a secondary school context: Negotiation of meaning in English as lingua franca/Spanish tandem interactions
}

\author{
Begoña Clavel-Arroitia \\ Departament de Filologia Anglesa i Alemanya \\ Facultat de Filologia, Traducció i Comunicació. Universitat de València. \\ begona.clavel@uv.es \\ Barry Pennock-Speck \\ Departament de Filologia Anglesa i Alemanya \\ Facultat de Filologia, Traducció i Comunicació. Universitat de València. \\ pennock@uv.es
}

Fecha presentación: 17/06/2015 | Aceptación: 22/09/2015 |Publicación: 22/06/2015

\section{Resumen}

En este artículo presentamos nuestra investigación sobre la negociación de significado en dos interacciones con los mismos estudiantes españoles y alemanes de 16 años de edad en colegios de España y Alemania respectivamente. Las interacciones incluyen dos constelaciones de idioma, es decir, inglés como lengua franca y un tándem español. Nuestra investigación se llevó a cabo dentro del proyecto Telecollaboration for Intercultural Language Acquisition project (TILA). Nuestro análisis cualitativo de la interacción demuestra que la telecolaboración ofrece muchas oportunidades para la comprensión y el aprendizaje. No hemos encontrado pruebas concluyentes para apoyar la hipótesis de que la negociación de significado es muy diferente en los dos tipos de constelaciones de idioma.

Palabras clave: Telecolaboración. Negociación de significado. Tándem. Lingua Franca.

\section{Resum}

En aquest article presentem la nostra investigació sobre la negociació de significat en dos interaccions amb els mateixos estudiants espanyols i alemanys de 16 anys d'edat en collegis d'Espanya i Alemanya respectivament. Les interaccions inclouen dos constelllacions d'idioma, és a dir, anglés com a llengua franca i un tàndem espanyol. La nostra investigació es va dur a terme dins del projecte Telecollaboration for Intercultural Language Acquisition project (TILA). La nostra anàlisi qualitativa de la interacció demostra que la telecol.aboració ofereix moltes oportunitats per a la comprensió i l'aprenentatge. No hem trobat proves concloents per a recolzar la hipòtesi de que la negociació de significat és molt diferent en els dos tipus de constel-lacions d'idioma.

Paraules clau: Telecol.laboració. Negociació de Significat. Tàndem. Llengua Franca.

\begin{abstract}
In this article we present our research into the negotiation of meaning in two interactions involving the same 16-year old Spanish and German students based in schools in Spain and German respectively. The interactions involved two language constellations, that is, English as a lingua franca and a Spanish tandem. Our research was carried out within the Telecollaboration for Intercultural Language Acquisition project (TILA). Our qualitative analysis of the interactions demonstrates that telecollaboration offers many opportunities for comprehension and learning. We have not found conclusive evidence to support the hypothesis that negotiation of meaning is very different in the two types of language constellation.
\end{abstract}

Key words: Telecollaboration. Negotiation of meaning. Tandem. Lingua Franca. 


\section{Introduction}

The research reported here is based on part of a corpus from the Telecollaboration for Intercultural Language Acquisition project (TILA), a project $^{1}$ funded by the EU. The main objective of TILA is to enhance foreign language teaching by implementing telecollaboration between European secondary schools. Another aim of TILA is to analyse the results of the implementation of telecollaboration to gauge its importance in the teaching and learning processes. The main beneficiaries of this project are secondary school students attending different schools in France, Germany, the Netherlands, Spain and the United Kingdom. The project started in 2013 and ended in June 2015. The universities involved are Universitat de València, University of Roehampton, Universiteit Utrecht, Univerzita Palackého, Universität Tübingen (Steinbeis Transfer Center Language Learning Media) and Université de Paris, 3.

The TILA project involves several tandem and lingua franca partnerships between the above schools. Tandems, as is well known, involve students with different mother tongues taking turns to teach and learn each other's mother tongue. Lingua franca exchanges, however, involve students learning a language which is not their own. Interestingly the lingua franca constellations are not only in English but in Spanish, French and German. In TILA we have several partnerships that are neither tandems or lingua franca constellations. For instance, we have groups made up of Spanish students learning English together with German or Dutch students learning Spanish. Of course, the German or Dutch students are not native speakers of English but their level of proficiency is undoubtedly much higher than that of the Spanish students and so they act as de facto native speakers. In the partnership we are analysing here the students are from a Spanish secondary school and a German Gymnasium. The students are sixteen years of age.

Our specific research objective here is to analyse aspects of the negotiation of meaning during synchronous telecollaboration tasks in Big Blue Button, a video conferencing programme that is similar to Skype but part of our Moodle platform. Our analysis will focus on the importance of the students' language and cultural background when interacting with peers and we will observe differences such as the provision of feedback when comparing interaction between native and nonnative speakers and interaction in the context of English as a lingua franca. We will also pay special attention to the differences, if any, in communicative strategies in the negotiation of meaning between nonnative speakers of English as a lingua franca and exchanges between native and non-native speakers of Spanish.

In order to do this, we will analyse a video sample and transcription of speech between non-native speakers using English as a lingua franca (nine minutes of transcription) and pairs of native and non-native speakers (fifteen minutes of transcription).

With regard to results, we have found no conclusive evidence that, at least in our small sample, the negotiation of meaning is very different when we compare tandems and lingua franca constellations. We

1 http://www.tilaproject.eu/moodle/ have discovered that similar strategies are used in both contexts.

\section{Computer-mediated communication and telecollaboration in L2 learning}

According to Lee (2001: 232), “online interactive exchange offers learners many opportunities to use the target language to negotiate both meaning and form in a social context that is crucial for second language acquisition (SLA)". It is precisely this type of interactive exchange that we find in the context of ComputerMediated Communication (CMC) in general and more particularly in Telecollaboration (TC). We agree with Lee (2001) that this type of synchronous electronic communication can provide learners with the opportunity to receive input and to produce output in the context of negotiation of meaning (these aspects are dealt with in section 5). The ultimate aim of CMC is to facilitate the existence of collaborative conversations between students that promote both the learning of a foreign language and the acquisition of intercultural communicative skills. CMC can encourage learners to participate and to learn from each other in an environment whose main characteristic, at least in the context of institutional settings such as secondary schools, is the possibility of talking to real speakers of a foreign language who are approximately of the same age. There has been a significant increase in the number of studies in the field of CMC and TC (Hewitt \& Brett, 2007; Su, Bonk, Magjuka, Xiaojing, \& Lee, 2005). We can also find quite a large number of studies focusing on intercultural aspects of communication and the development of Intercultural Communicative Competence (Belz, 2003; O'Dowd, 2003, 2007, Ware \& Kramsch, 2005). Other studies adopt an interactionist perspective and aim at analyzing participant interactions (Blake, 2000; Blake and Zyzik, 2003; Kötter, 2003; Smith, 2003, 2005; Sotillo, 2000). Fewer studies have focused on language form (Ware \& Cañado, 2007) or corrective feedback and the focus on form in telecollaboration (Iwasaki \& Oliver, 2003; Lee, 2006; Sotillo, 2005; Ware \& O'Dowd, 2008). Even less attention has been paid to the adequateness of the use of conversation logs as a teaching tool for learners (Schwienhorst, 2003; Sotillo, 2005).

It is therefore evident that further research is needed in this area and that studies that can shed light on aspects such as the negotiation of meaning among participants, corrective feedback and interaction are particularly necessary. Not enough attention has been paid to establishing an empirical relationship between measurements of learning and online learning environments that promote interaction and this is probably because language learning is a field which is very difficult to quantify. Furthermore, there is a need to identify the quality of negotiation of meaning in the completion of tasks carried out in a video-conferencing environment and the relevant factors (for instance, interactional modification and modified output) that can promote focus on form that may happen in those learning environments (Wang, 2006).

Following a growing body of research (Gass \& Varonis, 1985, 1986; Pica \& Doughty, 1985; Pica, 1994; Pica, Kanagy, \& Falodun, 1993; Scarcella \& Higa, 1981; Varonis \& Gass, 1985a; 1985b), it has been found that 
the type of interaction identified as "negotiation for meaning" provides optimal conditions for language acquisition because it provides learners with the opportunity to receive both input and produce modified output (Fernández-García and Martínez-Arbelaiz, 2002: 282). It is a common claim that the process of input, including both the comprehensible and noncomprehensible, kinds promotes comprehension and facilitates L2 learning and there have been several attempts to explain how this happens (Krashen, 1985: Long, 1996: White, 1987). According to Lee (2001), "receiving input itself without negotiated interaction is not sufficient. Learners must have the opportunity to take note of particular parts of linguistic structure and make an attempt to provide input modification". What is more, if we take a look at the output perspective, we must acknowledge the fundamental role of modified output together with negative feedback (Mackey, 1995; Schmidt, 1994; Tomlin and Villa, 1994). Moreover, pushed output, where students are at the limit of their communicative abilities in the foreign language, can help learners to acquire the L2, particularly in the case of syntactic structures (Swain, 1995).

If we take the theory of negotiation of meaning as a central argument which posits that interactional modifications make input more comprehensible and thus facilitate L2 acquisition, we must now find out how this can be carried out in distance learning environments. We will probably see that online learning settings can provide opportunities for negotiation of meaning as often as or even more frequently than in traditional classroom settings. Therefore the use of new technologies can help recreate the right environment for such interactional modifications to take place.

Regarding the type of model that we consider appropriate for learner interaction, we have chosen the one proposed by Varonis and Gass (1985b: 74):

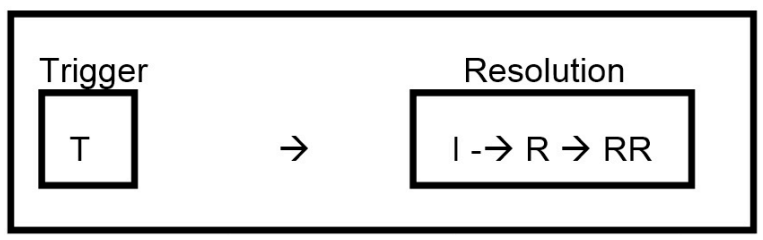

Figure 1: Proposed model for non-understandings (Varonis and Gass, 1985b: 74)

According to the authors, this is a two-part model consisting of a trigger and a resolution. The resolution consists, in turn, of an indicator, a response and a reaction to the response. Therefore, the trigger is the utterance or part of an utterance on the part of one of the speakers that results in some indication of nonunderstanding on the part of the hearer. The hearer, then, can either ignore the trigger or react to it somehow. Then, the resolution, as stated before, normally consists of an indicator, or an utterance on the part of the hearer that stops the horizontal progression of the conversation and starts the downward progression, the response, or the speaker's response to the indicator, and finally the reaction to the response, which is an optional element. This model has been applied to numerous studies of conversation analysis and it is particularly common in classroom discourse analysis. It is our belief that the negotiation of meaning that arises when a problem is posed in an interaction is at the heart of the process of learning a foreign language facilitating a wide variety of strategies, such as comprehension checks, clarification requests, repetitions, reformulations, among others, that can guarantee successful understanding and mutual comprehension.

\section{Computer-assisted Classroom Interaction}

According to Fernández-García and Martínez-Arbelaiz (2002: 280), “[a] few studies that have examined computer-assisted-classroom discussions (CACDs) suggest that the electronic environment provides optimal opportunities for language development (Beauvois, 1992; Chun, 1994; Kelm, 1992; Kern, 1995; Warschauer, 1996; Sullivan \& Pratt, 1996)". What is more, other studies (Varonis \& Gass, 1985b; Porter, 1986) have highlighted the advantages of instruction centred on the learner and the particular benefits of small group work since it provides opportunities for the learners to engage in discursive moves such as clarification requests, discussion initiations, interruptions, competition for the floor and joking. This is something that can often be found in TC, where pairwork and group work are usually the norm. Some examples of the use of these strategies are given in the results section. Online environments have been found to offer the potential to change the traditional roles performed by teachers and learners and to provide opportunities for learner output.

In this context, the choice of tasks is essential for the facilitation of this type of interaction and therefore task design should be given the importance it deserves in order to promote negotiation of meaning which would in turn result in acquisition of the target language. In our project, task design and implementation is considered of upmost importance. We follow a three-phase design model partly comparable to that proposed by Willis (1996):

1. Pre-Task

a) Introduction to topic and task

b) Exposure to real language

c) Use of texts, and activities based on them

2. Task Cycle
a) Task
b) Planning

i. draft and rehearse

ii. teacher helps with language

iii. emphasis on clarity, organization, accuracy

c) Report

3. Language Focus

a) Analysis

b) Practice

Tasks that are carefully designed and that can become a challenge for our students have a better chance of leading to student motivation and will at the same time provide the right setting for interactional strategies to be used more effectively by learners. 
Finally, we must take into account Walsh's (2002) perspective that suggests maximising learner involvement through the choice of language made by teachers in order to promote second language acquisition. Although, in our experience good TC interactions often do not necessitate direct involvement by the teacher, sometimes it might be felt to be needed. It is Walsh's (2002) view that teachers can either construct or obstruct learner participation in face-to-face classroom communication. Teachers can provide students with adequate tasks in an adequate setting for them to engage in negotiation of meaning and this can be very effectively done through TC. According to Walsh (2002: 10-13) some of the features that characterize teacher's language use which facilitates learner involvement are: direct error correction, content feedback, checking for confirmation, extended wait-time and scaffolding. In the results section, we will offer some examples of how the teachers and students in the transcripts engage in learning involvement and negotiation of meaning making use of some of these techniques.

\section{Methodology}

Our methodology takes the form of a qualitative analysis of the complete transcription of one of the telecollaborative exchanges between a Spanish and a German school that had been previously transcribed by hand from a video recorded in BBB. The interaction which takes place in the main task phase involves four students in both a lingua franca and a tandem constellation. In the first part of the exchange the students use the target language of the German students which is at the same time the native language of their Spanish peers. Therefore, the Spanish students acted as experts providing possible comprehensible input to the German learners. In the second part of the interaction, English is used by both groups of students and thus we find an example of the use of a lingua franca although the German students are much more proficient in this language than the Spanish students. We identified the students' use of strategies to negotiate meaning and the similarities and differences between these strategies in both situations. The triggers (Varonis and Gass, 1985b) in the transcription were identified and classified and are included in the excerpts below. The main methodology of our study has involved several steps:

1. designing and implementing an adequate task for our students that would promote interaction, participation and the acquisition of intercultural competence.

2. video- and audio-recording participant talk during task implementation

3. transcribing the talk

4. coding and examining the instances of negotiation

5. comparing both situations

We were especially interested in finding processes related to assistance (co-construction and othercorrection), self-correction and encouragements to continue or "continuers", using Foster and Ohta's (2005) terminology, which is also related to Walsh's (2002) teacher's construction of learner participation (including direct error correction, content feedback, checking for confirmation, extended wait-time and scaffolding) as stated above.

\section{Analysis and Results}

The analysis of the transcription sheds light on who is in control of the flow of discourse. With respect to the initial part of the session in which Spanish is the target language, S1 takes the initiative (S2 only intervenes briefly at the end of the English phase of the action) although the reasonably good level of the German students' Spanish allows them to participate quite interactively and they are capable of understanding and answering most of his questions. Nevertheless, it is S1 who takes it upon himself to be the guide throughout the interaction and also tries to maintain the flow of communication by reformulating, repeating and clarifying any utterance that he thinks might be causing a problem. $\mathrm{He}$ attempts to make sure that the German students understand everything he says. He is the only one to use repetition in the Spanish session - 23 times. He employs strategies such as comprehension check seven times out of eight, confirmation nine times out of ten and reformulation six times out of six. He also uses a slower tempo a technique to facilitate comprehension quite often throughout his intervention. However, in the second part of the interaction when the students are asked to switch to English, the S1 is at a disadvantage as he sometimes struggles to understand everything the German students are asking him. Thus, he finds himself at a disadvantage and loses the initiative to a certain extent, having to ask for clarification three times. It is then the German girls' turn to reformulate and repeat their questions so that he can understand, especially German student one (G1). Although S1 is the sole user of confirmation checks and reformulation, the German girls use repetition five times out of eight and confirmation three times out of six. There are also cases of total communication breakdown in this second part and the German students cannot help laughing (albeit in a well meaning way) at their Spanish counterparts' inability to understand them. During one of these occasions, the second Spanish speaker (S2) does not seem to understand them until they resort to translating their question into Spanish. Overall, the initial interaction in Spanish is more successful than the one in English due to the German students' good level of Spanish and the Spanish students' poor level of English respectively.

In the first part, the S1 uses different techniques when a trigger occurs: mainly repetition, reformulation, translation and expansion. He also uses preemptive strategies to avoid problems in communication. In these cases he uses confirmation check, topic continuation, repetition and translation. It is noticeable here how S1 uses some of these as strategies to solve a problem when it has already occurred or as a technique to prevent possible misunderstandings.

We have observed that linguistic mistakes are not corrected by a peer unless they constitute an obstacle for communication. For example, G1 uses "grupa" instead of "grupo" but this mistake is not corrected. The German teacher (GT) does give some feedback during the Spanish session, which is normally accepted by the German students, that is, uptake is quite frequent in 
those cases. There are also a few instances of peerfeedback that take the form of recasts:

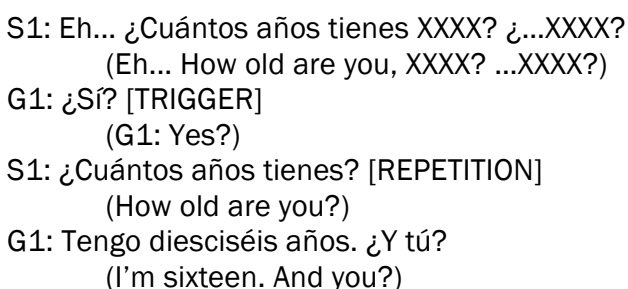

S1: Dieciséis también. Tenemos la misma edad ... Dieciséis años. [PEER-FEEDBACK: RECAST] Sixteen.....) (Sixteen too. We're the same age.

On one of the occasions, peer-feedback serves as reinforcement after teacher feedback has been provided:

S1: XXXX (name of G1), ¿cuándo es tu cumpleaños? Tu cumpleaños. [REPETITION] (XXXX (name of G1), when is your birthday? Your birthday.)

G1: Mi cumpleaños es, es en el ventiocho de disembre. [ERROR] Desember.) (My birthday, is on the twenty-eighth of

GT: Diciembre. [TEACHER FEEDBACK] (December.)

S1: Diciembre. [PEER-FEEDBACK] (December.)

S1: Diciembre. Muy bien. [REPETITION of PEERFEEDBACK and ACKNOWLEDGEMENT] (December. Very good.)

We can also find instances of scaffolding where the Spanish student tries to help his German counterpart when she has a problem expressing herself in Spanish. Furthermore, he praises her formulation or checks comprehension once she overcomes the problem and produces a correct utterance:

(She shows them the picture)

S1: ¿Cómo se llaman?

(What are their names?)

GT: Explica quién es. Quienes son.

(Tell them who it is. Who they are.)

G1: Eh... Son...

(Eh... They are...)

S1: Cómo se Ilaman. [SCAFFOLDING]

(What their names are.)

G1: Son XXXX y XXXX. Eh... Son mis amigas $y$ estamos a Roma a la foto.

(G1: They are XXXX y XXXX. Eh... They are my friends at Rome and we are at Rome at the photo.)

S1: Muy bien. [PRAISING/CONFIRMATION] (Very good.)

Another significant characteristic of this episode is the use of humour by the Spanish student. We believe this is partly because it is part of his nature, he probably wants to impress the German students, but this resource also acts as a way to keep the flow of conversation going and as a technique to maintain the attention among the participants. Here is an example of this:

S1: XXXX (name of G1), ¿tienes alguna mascota, en tu casa? home?)

(XXXX (name of G1), do you have a pet, at

G1: No, no tiene una mascota... ¿Y tú?

(No, she doesn't have a pet... And you?)

S1: Yo tampoco, pero tengo a mi hermana, que es suficiente. [USE OF HUMOUR]

(Neither do I, but I have my sister, that is enough.)

(G1: laughs)

Apart from the use of humour, we can see that the Spanish student is very willing to maintain the flow of communication using as many techniques as he can muster to facilitate interaction. On some occasions, he even reprimands his classmates when they are talking and/or laughing because he can't hear the German student. He also goes back to the previous topic after an interruption by one of the German students because he wants to finish his utterance where he praises the good use of Spanish of the German girls.

We must admit that sometimes he goes a bit too far and on one particular occasion he uses different techniques to maintain the flow of communication where a trigger has not even occurred and the German student makes him see that she had understood from the beginning when she says emphatically "Sí comprendo":

S1: Vale, pero bien. XXXX (name of G1), ¿cuántos años tiene, cuántos años tiene tu hermano? Tu hermano. Edad. Años. [REPETITION-EXPANSIONREFORMULATION]

(Ok, but yeah. XXXX (name of G1), how old is, how old is your brother? Your brother. Age. Years.)

G1: Sí, comprendo. (emphatic) Tiene vientidós años.

(Yes, I understand. He is twenty-two.)

It is clear from the transcript that the students are the real protagonists of the interaction and that the German teacher's interventions are not very frequent. He only intervenes at the beginning to ask Spanish students to speak more slowly, then to solve a technical problem related with sound, to reprimand them on the use of an inappropriate photo and to correct a couple of linguistic mistakes. We do not believe his interventions are disruptive and the students are able to maintain the conversation without much help from the teacher. However, we must highlight a particular mediation by the teacher:

(G1 speaks German G1 and G2).

GT: XXXX está buscando sus preparaciones. Os quiere contar algo sobre su familia. [TOPIC SHIFT Introduced by The teacher refering to the pretask]

(XXXX is looking for the stuff she has prepared. She wants to tell you something about her family. 


\section{S1: Vale, muy bien. [CONFIRMATION] (OK, very good.)}

Here we can observe how the teacher helps students with topic shift and resorts to information that they have previously prepared in the preparatory phase of the task. We assume that he wants them to use the vocabulary and structures that they have worked on during the pretask. This serves both as scaffolding technique and as topic shift.

If we turn our attention to the second part of the episode, we will observe that the Spanish student loses the floor here and due to his problems with the English language he can no longer remain in command. We find that some of the same techniques and strategies employed in the first part are also used here, but by the German girls, like for instance, repetition and confirmation checks.

However, the efforts on the part of the Spanish student to scaffold the conversation are worth mentioning here. It seems that as his English is not good enough to ask all the questions as he did in the first part, he now asks the German students to ask him more questions. This might be one way of maintaining some sort of control over the discourse:

G2. Sorry (they laugh) [German students make fun of the S1 because he didn 't understand a simple question]

S1. Ehm, ask me, please. [SCAFFOLDING-TOPIC CONTINUATION]

G1. What are your hobbies?

S1. My hobbies ... eh, I like play eh basketball and football. And tennis. Other sports I like it.

We can tell that the students are engaging in active conversation and that they enjoy the topic because they use different strategies to keep it going and there is no topic shift. At a certain point, you could even say that the teenagers are flirting, For example, when S1 says that S2 thinks that G1 is beautiful, and they are very interested in finding out if each of them has a girl-friend and a boyfriend respectively. G1 says that she is not beautiful enough to have a boyfriend and then admits when S1 says his friend thinks she is beautiful that she was only fishing for that particular compliment (last line of this dialogue). The following extract shows how they help to build the conversation in a collaborative way.

S1. Eh, eh, my friend has a question (friend lifts finger) that is if you, eh. Do you have a boyfriend? G1. Yes. (smiles) I don't (puts on glum face)

S1. Why?

G1. I think I am not beautiful enough (smiles friend smiles too).

S1. Ok. (looks at friend)

G1. Laughs

S1. He thinks (points to friend) that you are beautiful.

G1. Thank you. That is what I wanted to hear (smiling)

It is also worth mentioning that the German students have a better command of English and they can see that the Spanish students are not as good as they are. They poke fun at some of the mistakes they make and they even try to point out to $\mathrm{S} 2$ that he has made a mistake, but as he doesn't seem to understand, G1 has to switch to Spanish to highlight his error:

G1. How old are you?

S2. What? (S1 leaves) [TRIGGER-CLARIFICATION REQUEST]

G1. How old are you? [REPETITION]

S2. I'm fine. [TRIGGER -S2 misunderstands the questions and gives a different answer]

(G1 and G2 laugh. S1 comes back with a cloth over his head)

G1. ¿Cuántos años tienes? (How old are you?)

S2. He says he lives in Morocco (pointing to S1). [USE OF HUMOUR]

G1. I asked how old are you. Not how are you (laughs). [CLARIFICATION-EXPLANATION OF MISTAKE]

S2. What? [TRIGGER-CLARIFICATION REQUEST]

G1. ¿Cuántos años tienes? [TRANSLATION]

S2. 16. [CODE-SWITCHING]

Finally, possibly owing to the nature of this part of the exchange, where both groups of students are using a foreign language to communicate, there are more linguistic mistakes (most of them made by the Spanish students) but apart from the communication problem with $\mathrm{S} 1$ at the beginning of the English session and S2 at the end, communication is quite fluid. However, there is no feedback for those mistakes either from the students or teachers. The Spanish teachers are too busy looking after several groups of students to take an active part in the proceedings -they can be seen moving around the classroom in the background. The German teacher does not intervene very often, probably because the flow of communication is guaranteed thanks to the students' efforts to maintain the interaction, and the fact that the mistakes do not seem to obstruct comprehension. Here the probable causes of interruptions during the discourse are pronunciation problems or bad sound quality.

\section{Conclusions}

We have not found any conclusive evidence that the negotiation of meaning is very different during the lingua franca and tandem constellations that we have analysed. However, in both cases one set of students is vastly superior to the other. This would be expected in a true tandem with native speakers of both target languages. However, here, although during the Spanish session we are dealing with a true tandem situation, in which the Spanish are native speakers and the Germans are nonnative, in the English as lingua franca interactions the German students act as de facto native speakers. Normally one would expect two sides of a lingua franca to be at more or less the same level -this was at least attempted during the planning of the TILA sessions. However, as the German students' English is much better than their Spanish counterparts, we actually have something akin to a Spanish/English tandem constellation. We hypothesise that, in fact, many lingua franca interactions would probably involve students with different levels of English, French, German, Spanish, or whatever the lingua franca was. This would mean that they would be in the final analysis rather akin to tandems. 
It is clear that a much larger corpus is needed to discover whether there are differences between tandems and lingua franca interactions. This is not only true because lingua franca constellations may involve students from different countries with very different proficiency levels but also because of the fact that we may be dealing with interactions involving people with very different goals not always purely academic- as we have seen in our very small sample. The gender factor, especially considering the age of the learners we have been looking at, cannot be ignored nor can other factors such as ethnic origin or social class.

The most important outcome from our research is that meaning negotiations, such as the repair negotiations that Nakahama, Tyler and van Lier (2001: 388) analyse, "provide the ideal locus for learners to recognize the gap between their interlanguage grammar and the target grammar" and that the more of this type of negotiation there is, the more opportunities the students will have for comprehension and learning. They also remark that, following Swain (1985), longer and more complex utterances are needed for acquisition to take place (Nakahama, Tyler and van Lier, 2001: 388). Certainly, the type of peer interaction that takes place in our sample provides many opportunities that challenge the students' abilities to comprehend what is being said and to communicate their own ideas. Not only are students faced with difficulties with regard to syntax and vocabulary but also having to handle implicit communication. In this regard G1 is perfectly aware when S1's remarks could be construed as flirting or when S1 overdoes his attempts to make G1 understand a question: "cuántos años tiene tu hermano? Tu hermano. Edad. Años" (how old is, how old is your brother? Your brother. Age. Years) to which she replies emphatically "Sí, comprendo" (Yes, I understand). It would be difficult to find classroom exercises, such as gap fills, that could motivate and challenge students as much as the kind of interaction found in the TILA exchanges. Moreover, classroom exercises could never offer students the chance to interact with foreign peers to acquire intercultural competence. That is only possible in face-toface interactions, which would involve travelling expenses, or through telecollaboration.

\section{References}

Beauvois, Margaret Healey. (1992). Computer-assisted classroom discussion in the foreign language classroom: Conversation in slow motion. Foreign Language Annals, 25, pp. 455-464. doi: http://dx.doi.org/10.1111/j.19449720.1992.tb01128.x

Belz, Jackie. (2003). Linguistic perspectives on the development of intercultural competence in telecollaboration. Language Learning \& Technology, $7(2)$, pp. 68-117. Retrieved from http://It.msu.edu/vol7num2/belz/default.html

Blake, Robert. (2000). Computer mediated communication: A window on L2 Spanish interlanguage. Language Learning \& Technology, 4(1), 120-136. Retrieved from http://It.msu.edu/vol4num1/blake/default.html

Blake, R.; Zyzik, Eve. (2003). Who's helping whom?: Learner/heritage speakers' networked discussions in Spanish. Applied Linguistics, 24(4), pp. 519-544. doi: 10.1093/applin/24.4.519

http://dx.doi.org/10.1093/applin/24.4.519

Chun, Dorothy M. (1994). Using computer networking to facilitate the acquisition of interactive competence. System, 22 (1), pp. 17-31. doi: http://dx.doi.org/10.1016/0346-251X(94)90037-X

Fernández-García, Marisol; Asunción Martínez-Arbelaiz (2002). Negotiation of meaning in nonnative speakernonnative speaker synchronous discussions. CALICO Journal, 19(2), 279-284. doi: 10.1558/cj.v19i2.279284

Gass, Susan M.; Evangeline. M. Varonis (1985). Task variation and nonnative/nonnative negotiation of meaning. Input in Second Language Acquisition. Eds. S. M. Gass \& C. G. Madden. Rowley, MA: Newbury House, pp. 149-161.

Gass, Susan M.; Evangeline M. Varonis (1986). Sex differences in non-native speaker/nonnative speaker interactions. Talking to learn: Conversation in Second Language Acquisition. Ed. R. R. Day. Cambridge, MA: Newbury House, pp. 327-351.

Hewitt, Jim; Clare Brett (2007). The relationship between class size and online activity patterns in asynchronous computer conferencing environments. Computers and Education, 49(4), pp. 1258-1271. doi: http://dx.doi.org/10.1016/j.compedu.2006.02.001

Iwasaki, Junko; Rhonda Oliver (2003). Chat-line interaction and negative feedback. Occasional Thematic Issue of the Australian Review of Applied Linguistics (ARAL), 17, pp. 60-73.

Kelm, Orlando R. (1992). The use of synchronous computer networks in second language instruction: A preliminary report. Foreign Language Annals, 25 (5), pp. 441-453. doi: http://dx.doi.org/10.1111/j.19449720.1992.tb01127.x

Kern, Richard G. (1995). Restructuring classroom interaction with network computers: Effects on quantity and characteristics of language production. The Modern Language Journal, 79, pp. 457-476.

Kötter, Markus (2003). Negotiation of meaning and codeswitching in online tandems. Language Learning \& Technology, 7(2), 145-172. Retrieved from http://It.msu.edu/vol7num2/kotter/default.html

Krashen, Stephen (1985). The Input Hypothesis: Issues and Implications. New York: Longman.

Lee, Lina (2001). Online interaction: negotiation of meaning and strategies used among learners of Spanish. ReCALL, 13(2), 232-244. doi: http://dx.doi.org/10.1017/S0958344001000829a

Lee, Lina (2006). A study of native and nonnative speakers' feedback and responses in SpanishAmerican networked collaborative interaction. Internet-Mediated Intercultural Foreign Language Education. Eds. J. Belz \& S. Thorne. Boston: Thomson Heinle, pp. 147-176.

Long, Michael H. (1996). The role of the linguistic environment in second language acquisition. Handbook of Research on Language Acquisition. Vol. 2: Second Language Acquisition. Eds. W. C. Ritchie and T. K. Bhatia. New York: Academic, pp. 413-468.

Mackey, Alison (1995). Stepping up the place: input, interaction and interlanguage development. An empirical study of questions in ESL. Unpublished doctoral dissertation, University of Sydney, Australia. 
O'Dowd, Robert (2003). Understanding the 'other side': Intercultural learning in a Spanish-English e-mail exchange. Language Learning \& Technology 7(2), pp. 118-144. Retrieved from http://Ilt.msu.edu/vol7num2/odowd/default.html

O'Dowd, Robert (2007). Evaluating the outcomes of online intercultural exchange. ELT Journal 6(2), pp. 144-152. http://dx.doi.org/10.1093/elt/ccm007

Pica, Teresa (1994). Research on negotiation: What does it reveal about second-language learning conditions, processes, and outcomes? Language Learning, 44 (3), pp. 493-527. doi: http://dx.doi.org/10.1111/j.1467-

\subsection{4.tb01115.x}

Pica, Teresa; Catherine Doughty (1985). Input and interaction in the communicative language classroom: A comparison of teacher-fronted and group activities. Input in Second Language Acquisition. Eds. S. M. Gass and C. Madden. Rowley, MA: Newbury House, pp. 115-132.

Pica, Teresa; Ruth Kanagy; Joseph Falodun (1993). Choosing and using communication tasks for second language instruction and research. Tasks and Second Language Learning: Integrating Theory and Practice. Eds. G. Crookes and S. M. Gass. Clevedon: Multilingual Matters, Ltd, pp. 9-34.

Scarcella, Robin C.; Corrine Higa, (1981). Input, negotiation, and age differences in second language acquisition. Language Learning, 31 (2), pp. 409-438.

Schmidt, Richard W. (1994). Deconstructing consciousness in search of useful definitions for applied linguistics. AILA Review, 11, pp. 11-26.

Schwienhorst, Klaus (2003). Learner autonomy and tandem learning: Putting principles into practice in synchronous and asynchronous telecommunications environments. Computer Assisted Language Learning, 16(5), pp. 427-443. doi: http://dx.doi.org/10.1076/call.16.5.427.29484

Smith, Bryan (2003). Computer-mediated negotiated interaction: An expanded model. The Modern Language Journal, 87(1), pp. 38-57. doi: http://dx.doi.org/10.1111/1540-4781.00177

Smith, Bryan (2005). The relationship between negotiated interaction, learner uptake, and lexical acquisition in task-based computer-mediated communication. TESOL Quarterly, 39(1), pp. 33-58. http://dx.doi.org/10.2307/3588451

Sotillo, Susana M. (2000). Discourse functions and syntactic complexity in synchronous and asynchronous communication. Language Learning \& Technology, 4(1), pp. 82-119. Retrieved from http://It.msu.edu/vol4num1/sotillo/default.html

Sotillo, Susana M. (2005). Corrective feedback via Instant Messenger learning activities in NS-NNS and NNSNNS dyads. CALICO Journal, 22(3), pp. 467496.

Su, Bude; Curtis J. Bonk; Richard J. Magjuka; Liu Xiaojing; Seung-hee Lee (2005). The importance of interaction in web-based education: A program-level case study of online MBA courses. Journal of Interactive Online Learning, 4(1), pp. 1-19.

Sullivan, Nancy; Ellen Pratt, (1996). A comparative study of two ESL writing environments: A computer-assisted classroom and a traditional oral classroom. System,
29 ,

pp.

491-501.

doi:

http://dx.doi.org/10.1016/S0346-251X(96)00044-9

Swain, Merill (1995). Three functions of output in second language learning. Principle and Practice in Applied Linguistics: Studies in Honor of $H$. G. Widdowson. Eds. G. Cook. and B. Seidlhofer. Oxford: Oxford University Press, pp. 125-144.

Tomlin, Russell S.; Victor Villa (1994). Attention in cognitive science and second language acquisition. Studies in Second Language Acquisition, 16: pp. 183-204. http://dx.doi.org/10.1017/S0272263100012870

Varonis, Evangeline M.; Susan Gass (1985a). Miscommunication in native/non-native conversation. Language in Society, 14 (3), pp. 327343.

Varonis, Evangeline M.; Susan Gass (1985b). Nonnative/non-native conversations: A model for the negotiation of meaning. Applied Linguistics, 6, pp. 71-90. doi: http://dx.doi.org/10.1093/applin/6.1.71

Walsh, Steve (2002). Construction or obstruction: teacher talk and learner involvement in the EFL classroom. Language Teaching Research, 6(1), pp. 323. doi: http://dx.doi.org/10.1191/1362168802Ir095oa

Wang, Yuping (2006). Negotiation of meaning in desktop videoconferencing-supported distance language learning. ReCALL, 18(1), pp. 122-145. http://dx.doi.org/10.1017/S0958344006000814

Ware, Paige; Maria Luisa Pérez-Cañado (2007). Grammar and feedback: Turning to language form in telecollaboration. Online Intercultural Exchange: An Introduction for Foreign Language Teachers. Ed. R. O'Dowd. Clevedon: Multilingual Matters, pp. 107126.

Ware, Paige; Claire Kramsch (2005). Toward an intercultural stance: Teaching German and English through telecollaboration. The Modern Language Journal, 89(2), pp. 190-205. doi: http://dx.doi.org/10.1111/j.15404781.2005.00274.x

Ware, Paige; Robert O'Dowd (2008). Peer feedback on language form in telecollaboration. Language Learning \& Technology, 12(1), pp. 43-63. Retrieved from http://Ilt.msu.edu/vol12num1/wareodowd/default.ht $\mathrm{ml}$

Warschauer, Mark (1996). Comparing face-to-face and electronic discussion in the second language classroom. CALICO Journal, 13, pp. 7-25.

White, Lydia (1987). Against comprehensible input: the input hypothesis and the development of L2 competence. Applied Linguistics, 8, pp. 95-110.

Willis, Jane (1996). A Framework for Task-based Learning. London: Longman. 
Otoño (Julio-Diciembre 2015) N. 15. Págs. 9

| Cita recomendada de este artículo:

Clavel-Arroitia, Begoña y Barry Pennock-Speck. "Telecollaboration in a secondary school context: Negotiation of meaning in English as a lingua franca/Spanish tandem interactions". @tic. revista d'innovació educativa. 15. 2015: 7481. 